\title{
Spontaneous hypoglycemia: a review
}

\author{
Sultana Marufa Shefin ${ }^{1}$, Nazmul Kabir Qureshi ${ }^{2}$, Ahmed Salam Mir ${ }^{3}$, Ahasnul Haq Amin ${ }^{4}$, Tareen \\ Ahmed $^{5}$, Faria Afsana ${ }^{1}$, Md. Shah Alam ${ }^{6}$, Farhana Akter ${ }^{7}$, Md. Shah Emran ${ }^{8}$, Tanjina Hossain ${ }^{9}$, \\ Md. Shahjamal Khan ${ }^{10}$, Marufa Mustari ${ }^{11}$, Nusrat Sultana ${ }^{11}$, Mohammad Saifuddin ${ }^{12}$, Sadiqa \\ Tuqan $^{13}$, Shahjada Selim ${ }^{11}$, Samir Kumar Talukder ${ }^{14}$, Rafiq Uddin ${ }^{7}$, Md. Feroz Amin ${ }^{1}$
}

\begin{abstract}
${ }^{I}$ Department of Endocrinology, BIRDEM General Hospital, Dhaka. Bangladesh; ${ }^{2}$ National Health Care Network, Uttara, Dhaka, Bangladesh; ${ }^{3}$ Department of Endocrinology, Dhaka Central International Medical College, Dhaka, Bangladesh; ${ }^{4}$ Apollo Hospital Ltd., Dhaka, Bangladesh; ${ }^{5}$ Health Education Department, BIRDEM General Hospital, Dhaka, Bangladesh; ${ }^{6}$ Comilla Diabetic Hospital, Comilla, Bangladesh; ${ }^{7}$ Department of Endocrinology, Chittagong Medical College and Hospital. Chittagong, Bangladesh; ${ }^{8}$ Department of Endocrinology, MAG Osmani Medical College and Hospital, Sylhet, Bangladesh; ${ }^{9}$ Department of Endocrinology, Green Life Medical College and Hospital, Dhaka, Bangladesh; ${ }^{10}$ Department of Endocrinology, Enam Medical College and Hospital, Dhaka, Bangladesh; ${ }^{11}$ Department of Endocrinology, BSMMU, Dhaka, Bangladesh; ${ }^{12}$ Abdul Malek Ukil Medical College and Hospital, Noakhali, Bangladesh; ${ }^{13}$ Square Hospital Ltd., Dhaka, Bangladesh; ${ }^{14}$ Department of Endocrinology, Rangpur Medical College and Hospital. Rangpur, Bangladesh
\end{abstract}

\begin{abstract}
Spontaneous hypoglycemia is an important entity that may affect multiple organs. The differential diagnosis is broad in individuals with hypoglycemia in the absence of diabetes mellitus. Multiple etiologies may be present concurrently. Drugs, critical illnesses, hormone deficiencies, and non-islet cell tumors should be considered in those who are ill or taking medications. In apparently healthy individuals, endogenous hyperinsulinism due to insulinoma, functional $\beta$-cell disorders, or insulin autoimmune conditions are possible, as are accidental, surreptitious or factitious causes of hypoglycemia. Investigations should be guided by clinical scenario. Irrespective of the exact cause of the spontaneous hypoglycemia, treatment consists of correcting the glycemic state and preventing recurrence by alleviating underlying pathology. This review discusses the causes, diagnosis and management of spontaneous hypoglycemia.
\end{abstract}

IMC J Med Sci 2019; 13(1): 001. EPub date: 24 January 2019

\section{Introduction}

In our day to day clinical practice, hypoglycemia is a common clinical problem in patients with diabetes mellitus (DM) using insulin or insulin secretagogues for maintaining the recommended glycemic status [1]. The diagnosis and treatment of a hypoglycemic event in a diabetic case, having medication to lower plasma glucose level are therefore simple. However, hypoglycemia occurring spontaneously in a person without diabetes, a condition referred to as a 'spontaneous hypoglycemia' is a puzzling clinical problem and needs its understanding both by the endocrinologist and physicians of all disciplines.

Glucose homeostasis in the human body is under strict and continuous regulation of multiple hormones, the delicate balance of which maintains plasma glucose concentrations within the normal range to ensure sufficient nutritional support to organs. Spontaneous hypoglycemia is therefore, an important entity that may affect multiple organs in the body with a wide spectrum of clinical manifestations with significant morbidity in the affected individual [2].

Address for Correspondence:

Dr. Sultana Marufa Shefin, Assistant Professor, Department of Endocrinology, BIRDEM General Hospital, 122 Kazi

Nazrul Islam, Shahbag, Dhaka, Bangladesh.Email: shefin neon@yahoo.com 
In response to a falling blood glucose level, our body sets up an adaptive response that consists of rapid decline of endogenous insulin secretion, augmented glucagon secretion and sympathetic over-activity. This response is further enhanced with increased secretion of growth hormone and cortisol. When these adaptive physiological mechanisms fail, hypoglycemia becomes evident. Hence, spontaneous hypoglycemia merits a critical consideration in nondiabetic subjects $[3,4,5]$.

The metabolic homeostasis of glucose in the body depends on several glucoregulatory organs such as pancreas, liver, adrenal glands, kidneys, pituitary gland, and the hypothalamus. It is also under the strict control of multiple hormones namely insulin, glucagon, catecholamines, cortisol, and growth hormone [6]. Hence, spontaneous hypoglycemia is unlikely without significant derangements of these systems [2].

Hypoglycemia may develops when the glucose utilization from blood by brain, red blood cells, renal medullae and insulin sensitive tissues, such as muscles exceeds glucose delivery into circulation from dietary carbohydrates and glucose produced from liver and kidneys [6,7]. Under physiological condition, glucose production is high when in need. Hypoglycemia may occur when this capacity falls absolutely or relatively below glucose utilization. In profound hypoglycemia, assays reveal derangement of plasma insulin, C-peptide and pro-insulin levels [6-8]. Therefore, recent progress in identifying etiology, diagnosis and management of spontaneous hypoglycemia is discussed in this review.

\section{Evaluation, etiology and diagnosis of hypoglycemia}

The diagnostic process starts by the recognition of hypoglycemia as a cause of the presenting symptoms such as confusion, altered level of consciousness, seizure or any of the other autonomic and neuroglycopenic symptoms as mentioned in Table-1 [5, 9]. Diagnosis is difficult because the symptoms are not exclusive for hypoglycemia. Confirmation is done by documenting Whipple's triad $[10,11]$. The triad consists of (i) symptoms or signs consistent with hypoglycemia [Table 1], (ii) a plasma glucose level less than $55 \mathrm{mg} / \mathrm{dl}(3.1 \mathrm{mmol} / \mathrm{L})$ in venous blood sample and (ii) resolution of symptoms after raising plasma glucose level [11].

After documenting Whipple's triad, the two key elements in the management of non-diabetic subjects with hypoglycemia are: (a) identification of the hypoglycemic etiopathology, and (b) management of the low blood glucose level [8].

Table-1: Symptoms of hypoglycemia [9].

\begin{tabular}{ll}
\hline $\begin{array}{l}\text { Autonomic } \\
\text { (Adrenergic \& } \\
\text { cholinergic) }\end{array}$ & Neuroglycopenic \\
\hline Sweating & Behavioral changes \\
Anxiety & Visual changes \\
Tremor & Confusion/difficulty speaking \\
Nausea & Dizziness/lightheadedness \\
Warmth & Lethargy \\
Palpitations & Seizure/ convulsion \\
Tachycardia & Loss of consciousness \\
Hunger & Coma \\
\hline
\end{tabular}

Symptoms that arise first are the autonomic symptoms, mediated by the adrenergic and cholinergic axes of the sympathetic nervous system. Adrenergic symptoms consist of palpitations, tremor, and anxiety and are mediated by an up-regulation of norepinephrine and epinephrine. Cholinergic symptoms include hunger, sweating, and paresthesia and are derived from the acetylcholine released by postganglionic sympathetic neurons. These responses are part of the physiological counter regulatory mechanism, directed against a decrease in plasma glucose level [3,11]. Although, the sympathetic response generates the first type of symptoms, it is not the first counter regulatory mechanism against hypoglycemia. The first physiological response to a decreasing plasma glucose level is a down-regulation of insulin secretion, followed by a second defense of heightened glucagon secretion when blood glucose level falls below $70 \mathrm{mg} / \mathrm{dl}(3.9 \mathrm{mmol} / \mathrm{L})$. Only when these fail to halt the decreasing plasma glucose, a sympathetic response becomes apparent when blood glucose level falls below $60 \mathrm{mg} / \mathrm{dl}(3.3 \mathrm{mmol} / \mathrm{L})$ $[4,12]$. The second type of symptoms is the neuroglycopenic symptoms. These symptoms arise due to central nervous system glucose deprivation when blood glucose level falls below $50 \mathrm{mg} / \mathrm{dl}(2.8$ $\mathrm{mmol} / \mathrm{L}$ ). Neuroglycopenic symptoms range from 
confusion to amnesia, blurred vision, diplopia, dysarthria, seizure and if sufficient, profound loss of consciousness [13]. Prolonged hypoglycemia can cause brain death and hypoglycemia has shown to increase all-cause mortality in cardiac patients $[14,15]$. Mortality is especially higher for the spontaneous hypoglycemia in non-diabetics [16].

The presence of neuroglycopenic symptoms in patients without diabetes is strongly suggestive of a hypoglycemic disorder [17]. Conversely, there is a low likelihood of a hypoglycemia disorder in those with the presence of neurogenic symptoms in the absence of a low plasma glucose concentration [18]. Capillary blood glucose measurements should not be used in the evaluation of hypoglycemia due to poor accuracy [17]. Symptoms of hypoglycemia may be absent in patients with hypoglycemia due to decreased sympathetic response to recurrent hypoglycemia, prior exercise or sleep [17,19-21].

Hypoglycemia disorders are traditionally classified as being post absorptive hypoglycemia (fasting hypoglycemia) and postprandial hypoglycemia (reactive hypoglycemia). Fasting hypoglycemia is caused by organic pathologies that presents mostly with neuroglycopenic symptoms and re-active hypoglycemia arises from functional disorder which presents often with autonomic features. An insulinoma can present with postprandial or a postabsorptive hypoglycemia [4,5,22]. This approach has limitation as it neither expedites diagnosis nor facilitates an understanding of the pathophysiology of the disorders.

The differential diagnosis is broad when hypoglycemia occurs in individuals with hypoglycemia in the absence of diabetes mellitus (Table 2) [17]. Multiple etiologies may be present concurrently. Different causes of hypoglycemia should be considered in patients who are apparently healthy compared to those who are ill. Drugs, critical illnesses, hormone deficiencies, and non-islet cell tumors should be considered in those who are ill or taking medications. In apparently healthy individuals, endogenous hyperinsulinism due to insulinoma, functional $\beta$ cell disorders, or insulin autoimmune conditions are possible, as are accidental, surreptitious or factitious causes of hypoglycemia. Hypoglycemia in patients who have had bariatric surgery is increasingly recognized as the frequency of this surgery is in increase. Artifactual hypoglycemia can occur if blood samples are improperly handled (lack of antiglycolytic agent in the collection tube) and there is a delay in processing.

Drugs are the most common cause of hypoglycemia (Table 3) [17]. Drug induced hypoglycemia is more common in older patients with underlying comorbidities and in those taking glucose lowering medications. Hypoglycemia in the setting of critical illness is not unusual. Sepsis, hepatic, renal or cardiac failure and hormone deficiencies (cortisol, glucagon and epinephrine) are other causes of hypoglycemia. Non-islet cell tumors and endogenous hyperinsulinism such as insulinoma, non insulinoma pancreatogenous hypoglycemia, and autoimmune hypoglycemia are rare causes of hypoglycemia [17]. Accidental, surreptitious or malicious hypoglycemia due to administration of insulin or insulin secretagogues need also to be considered.

Table-2: Causes of hypoglycemia in adults [17].

\begin{tabular}{l}
\hline Etiology \\
\hline Drugs \\
Hepatic, renal or cardiac failure \\
Sepsis, trauma, burns \\
Malnutrition \\
Hormonal deficiencies (cortisol, glucagon, \\
epinephrine) \\
Non-islet cell tumors (IGF II secreting tumors) \\
Insulinoma (insulin secreting tumors) \\
Non-insulinoma pancreatogenous hypoglycemia \\
(NIPHS) \\
Post gastric bypass hypoglycemia \\
Insulin antibodies \\
Insulin receptor antibodies \\
Accidental, surreptitious or malicious \\
hypoglycemia
\end{tabular}

Insulinomas primarily cause hypoglycemia in the fasting state, but may cause symptoms in the postprandial period as well. The incidence is $1 / 250,000$ patient/years. Less that $10 \%$ are malignant, or may be present in patients with multiple endocrine neoplasia type 1 (MEN1) syndrome [17]. Non-insulinoma pancreatogenous hypoglycemia( NIPHS) typically causes hypoglycemia in the postprandial state. These patients have diffuse islet involvement with 
nesidioblastosis (islet hypertrophy, hyperplasia and enlarged hyperchromatic $\beta$-cell nuclei) [23].

Table-3: Drugs associated with hypoglycemia [17].

\begin{tabular}{|c|c|}
\hline $\begin{array}{l}\text { Good quality } \\
\text { evidence }\end{array}$ & $\begin{array}{l}\text { Very low quality } \\
\text { evidence }\end{array}$ \\
\hline $\begin{array}{l}\text { Insulin } \\
\text { Insulin secretagogues } \\
\text { Alcohol } \\
\text { Cibenzoline } \\
\text { Glucagon ( during } \\
\text { endoscopy) } \\
\text { Indomethacin } \\
\text { Pentamidine } \\
\text { Quinine } \\
\text { Artesunate/artemisin/ } \\
\text { artemether } \\
\text { Chloroquineoxaline } \\
\text { sulfonamide } \\
\text { IGF 1 } \\
\text { Lithium } \\
\text { Propoxyphine/dextro } \\
\text { propoxyphene }\end{array}$ & $\begin{array}{l}\text { Angiotensin converting } \\
\text { enzyme inhibitors } \\
\text { Angiotensin receptor } \\
\text { antagonist } \\
\text { Adrenergic receptor } \\
\text { antagonist } \\
\text { Fluroquinolones } \\
\text { Mifepristone } \\
\text { Disopyramide } \\
\text { Trimethoprim } \\
\text { sulfamethoxazole } \\
\text { Heparin } \\
6 \text { Mercaptopurine }\end{array}$ \\
\hline
\end{tabular}

Antibodies to insulin or the insulin receptor are rare causes of hypoglycemia $[17,18]$. Antibodies to native insulin occur primarily in patients of Japanese and Korean descent [24]. Patients with autoimmune hypoglycemia may have other autoimmune disease or exposure to sulfhydryl containing drugs [25]. Late postprandial hypoglycemia occurs as insulin secreted in response to the meal disassociates from antibodies. Diagnosis is made with documentation of elevated insulin antibody levels in the absence of exposure to exogenous insulin [26].

Spontaneous hypoglycemia can rarely be a result of paraneoplastic syndrome secondary to non-betacells tumors and is termed as non-islet cell tumor hypoglycemia (NICTH). A variety of malignant and non-malignant tumors such as solitary fibrous tumor and/or mesotheliomas, hemangiopericytoma, hepatocellular carcinoma, gastrointestinal stromal tumors, adenocarcinomas, sarcomas, and renal cell carcinomas may cause NICTH [27]. Unusual cases of NICTH have been reported with adrenocortical and thyroid cancers, Burkitt's lymphoma, plasmacytoma, yolk cell tumor, Leydig cell tumor, and phyllodes tumor of the breast. These tumors secrete partially processed precursors of insulin-like growth factorII (IGF-II), otherwise termed 'big'-IGF-II or pro IGF-II that causes NICTH [27,28]. Big IGF-II interacts with IGF-I receptors and insulin receptors in the target tissues and results in hypoglycemia [2].

Consideration for hormone deficiencies and nonislet cell tumors should be given. When adrenal insufficiency is considered, an ACTH stimulation test should be performed. If the cause of hypoglycemia is not apparent then further laboratory testing is indicated. Capillary blood glucose measurements should not be used in the diagnosis of hypoglycemic disorders due to their poor accuracy in these situations. If possible, testing should be done during symptomatic hypoglycemia. Simultaneous measurements of plasma glucose, insulin, c-peptide, proinsulin, and beta-hydroxybutyrate and a screen for oral hypoglycemic agents (sulfonylureas and meglitinide) should be performed (Table 4).

The tests described in the Table- 4 are useful to identify the causes of spontaneous hypoglycemia. If testing cannot be performed during a spontaneous episode of hypoglycemia, either a $72 \mathrm{hrs}$ fast test or a mixed meal test should be done in a monitored setting followed by administration of glucagon. The most useful diagnostic strategy is described below. The choice of test is based on the circumstances in which hypoglycemia is most likely to occur [2].

Seventy two hours fast test: For evaluation of spontaneous hypoglycemia, the 72 hours supervised fast test is the gold standard procedure. During this prolong fasting hypoglycemia is detected and etiology is evaluated. This test is done in hospital setting having monitoring facilities. During a 72 hour fast, patients are allowed no food but can consume non caloric caffeine free beverages. The onset of the fast is the time of the last food consumption. During the fast all nonessential medications should be discontinued. Simultaneous insulin, c-peptide and glucose samples should be obtained at the beginning of the fast and every 4-6 hours. When the plasma glucose falls to $<60$ $\mathrm{mg} / \mathrm{dl}$, specimens should be taken every 1 to 2 hourly under close supervision. Patients should continue activity when they are awake. The fast is terminated when plasma glucose falls below $45 \mathrm{mg} / \mathrm{dl}$ (2.5 mmol/l) and symptoms of neuroglycopenia develop. Plasma glucose less than $55 \mathrm{mg} / \mathrm{dl}(3.0$ 
Table-4: Interpretation of biochemical findings during a spontaneous hypoglycemia, fasting hypoglycemia or after a mixed meal

\begin{tabular}{|c|c|c|c|c|c|c|c|c|c|}
\hline Symptoms & $\begin{array}{l}\text { Glucose } \\
\text { (mg/dl) }\end{array}$ & $\begin{array}{c}\text { Insulin } \\
(\mathrm{pmol} / \mathrm{L})\end{array}$ & $\begin{array}{c}\text { C-peptide } \\
\text { (nmol/L) }\end{array}$ & $\begin{array}{c}\text { Pro- } \\
\text { insulin } \\
(\mathrm{pmol} / \mathrm{L})\end{array}$ & $\begin{array}{c}\text { Beta } \\
\text { hydroxy- } \\
\text { butyrate } \\
(\mathrm{mmol} / \mathrm{L})\end{array}$ & $\begin{array}{l}\text { Glucose } \\
\text { after } \\
\text { glucagon } \\
\text { (mg/dl) }\end{array}$ & $\begin{array}{c}\text { Circulating } \\
\text { OHA }\end{array}$ & $\begin{array}{l}\text { Insulin } \\
\text { Antibody }\end{array}$ & $\begin{array}{c}\text { Diagnostic } \\
\text { interpretation }\end{array}$ \\
\hline No & $<55$ & $<20.835$ & $<0.2$ & $<5$ & $>2.7$ & $<25^{\mathrm{a}}$ & No & No & Normal \\
\hline Yes & $<55$ & $>20.835$ & $<0.2$ & $<5$ & $<2.7$ & $>25$ & No & $\mathrm{No}^{\mathrm{b}}$ & $\begin{array}{l}\text { Exogenous } \\
\text { insulin }\end{array}$ \\
\hline Yes & $<55$ & $>20.8353$ & $>0.2$ & $>5$ & $<2.7$ & $>25$ & No & No & $\begin{array}{l}\text { Insulinoma, } \\
\text { NIPHS, PGBH }\end{array}$ \\
\hline Yes & $<55$ & $>20.8353$ & $>0.2$ & $>5$ & $<2.7$ & $>25$ & Yes & No & OHA \\
\hline Yes & $<55$ & $>20.8353$ & $>0.2$ & $>5^{\mathrm{c}}$ & $<2.7$ & $>25$ & No & Yes & $\begin{array}{l}\text { Insulin } \\
\text { autoimmunity }\end{array}$ \\
\hline Yes & $<55$ & $<20.8353$ & $<0.2$ & $<5$ & $<2.7$ & $>25$ & No & No & IGF mediated $^{\mathrm{d}}$ \\
\hline
\end{tabular}

$\mathrm{mmol} / \mathrm{l})$ is an alternative end point if Whipple's triad has been previously documented [17]. Additional samples for insulin antibodies, anti-insulin receptor antibodies, IGF1/ IGF2 and plasma cortisol, glucagon or growth hormone can also be obtained if a nonislet cell tumor, autoimmune etiology, or hormone deficiency is suspected. Follow up with a glucagon tolerance test is frequently done to aid in diagnosis [Glucagon, $1 \mathrm{mg} \mathrm{IV}$, administered with careful follow up of the glucose response every 10 minutes for 30 minutes. Further details regarding the glucagon tolerance test are below. Patients are fed at the conclusion of the fast. The diagnosis of endogenous hyperinsulinism is supported if insulin, c-peptide and proinsulin levels are inappropriately elevated in the setting of hypoglycemia (Table 4). Betahydroxybutyrate $<2.7 \mathrm{mmol} / 1$, and an increase in plasma glucose $\geq 25 \mathrm{mg} / \mathrm{dl}$ ( $1.4 \mathrm{mmol} /$ liter $)$ after IV glucagon indicates mediation of the hypoglycemia by either insulin (endogenous or exogenous) or an IGF excess [14]. It has been suggested that an amended insulin:glucose ratio, which subtracts 30 $\mathrm{mg} / \mathrm{dL}(1.7 \mathrm{mmol} / \mathrm{L})$ from the measured glucose, may be helpful in ruling out suspected insulinomas, but this remains controversial. In patients with laboratory assessments consistent with endogenous hyperinsulinism, negative screening for oral hypoglycemic agents (sulfonylureas/meglitinide) and negative insulin antibodies are suggestive of an insulinoma, non - insulinoma - pancreatogenous hypoglycemia (NIPHS), or post gastric bypass hypoglycemia [Table 4]. Approximately $75 \%$ of patients with insulinomas are diagnosed after a 24 hour fast and $90-94 \%$ at 48 hours. Although some experts advocate conducting the prolonged fast for only 48 hours others disagree, arguing that prolonging the fast up to 72 hours minimizes misdiagnosis and maximizes the probability of diagnosing an insulinoma.

Limitations of the prolonged fast include (a) normal subjects, especially young women, can occasionally have plasma glucose levels of $<40 \mathrm{mg} / \mathrm{dl} \quad(2.2$ $\mathrm{mmol} / \mathrm{l})$, (b) rare insulinomas suppress their release of insulin in response to hypoglycemia and (c) insulin levels can sometimes be artificially elevated in the presence of anti-insulin antibodies.

Glucagon tolerance test: The glucagon tolerance test serves as a supplemental study to aid in determining the etiology of hypoglycemia. Following an overnight fast, $1 \mathrm{mg}$ of glucagon is injected intravenously over 2 minutes. Plasma glucose and insulin levels are measured at baseline and either at 10, 20, and 30 minutes or at $3,5,10,15,20$ and 30 minutes after glucagon injection.

In normal patients, maximum insulin response occurs rapidly and usually does not exceed $694.5 \mathrm{pmol} / \mathrm{L}$ [30]. Insulinoma patients demonstrate an exaggerated insulin response to glucagon, with values often 
exceeding 1,111.2 pmol/L within 15-30 minutes of the injection [27]. In the hypoglycemic patient at the conclusion of the prolonged fast, an increase in plasma glucose of $>25 \mathrm{mg} / \mathrm{dl}(1.4 \mathrm{mmol} / \mathrm{l})$ postglucagon suggests an insulin mediated etiology [18].

Patients with malnutrition or hepatic disease may be unable to have a hyperglycemic response to glucagon due to depleted hepatic glycogen stores. Insulin responses in these subjects may be increased but not to the degree seen in subjects with an insulinoma. Drugs such as diazoxide, hydrochlorothiazide and diphenylhydantoin can cause false negative results [30]. Patients with nonislet cell tumors such as hemangiopericytomas and meningeal sarcomas can have similar glucose elevations $(30 \mathrm{mg} / \mathrm{dl})$ as subjects with insulinomas following glucagon injection [31].

Another limitation of the glucagon stimulation test is the failures of some insulinoma patients to hyper secrete insulin following glucagon injection. This problem was reported in $8 \%$ of patients with insulinomas in one study [30]. In addition, patients with cirrhosis with portocaval anastomosis can have peak insulin levels that are indistinguishable from subjects with insulinomas. Obese subjects and patients with acromegaly can also have exaggerated peak insulin responses, as can patients be treated with sulfonylurea drugs and aminophylline.

An additional disadvantage of this test is the danger of causing hypoglycemia after $90-180 \mathrm{~min}$ [32], as well as inducing nausea and vomiting. Because of the possibility of severe hypoglycemia, a physician needs to be present during the test [26].

Mixed meal test: For patients with hypoglycemic symptoms several hours after meals, a mixed meal test may be performed. This test has not been well standardized. This test is typically done after an overnight fast. Patients eat a meal similar to one that provokes their symptoms. If this is not possible then a commercial mixed meal may be used. Patients are then observed for several hours. Samples for plasma glucose, insulin, c-peptide, and pro-insulin are collected prior to the meal and every 30 minutes thereafter, for 5 hours. If symptoms occur prior to the end of the test then additional samples for the above are collected prior to administration of carbohydrates. If Whipple's triad is documented, testing for oral hypoglycemic drugs and testing for insulin antibodies should be done. Interpretation of test results is the same as for the 72 hour fast or spontaneous hypoglycemia (Table 4) [26].

Continuous glucose monitoring (CGM): CGM has been reported to detect more hypoglycemia than the mixed meal tolerance test. Though CGM devices may be helpful in detecting hypoglycemia in selected patients, their use is not recommended for the diagnosis of hypoglycemic disorders in people without diabetes [26].

Insulin, C-peptide and C-peptide suppression tests: Autoimmune hypoglycemia is a rare condition whereby antibodies, either directed against insulin or against the insulin receptor, are responsible for hypoglycemia. Autoimmune hypoglycemia due to insulin antibodies should be suspected when the hypoglycemia is associated with high insulin levels (usually $>100 \mathrm{uU} / \mathrm{ml}$ ) and incompletely suppressed C-peptide levels. Insulin levels are rarely $>100 \mathrm{uU} / \mathrm{ml}$ in the presence of hypoglycemia due to an insulinoma. Although these elevated insulin levels can be observed with exogenous insulin administration, the associated c-peptide levels are usually extremely low. Autoimmune hypoglycemia is most often seen in people of Japanese descent, but has been described in other populations [33]. Autoimmune hypoglycemia may also be due to antibodies to the insulin receptor. These patients will have mildly elevated insulin levels (thought to be due to decreased clearance of insulin) and suppressed c-peptide levels, and may have other autoimmune conditions [28]. Insulin antibody testing does not need to be done at the time of hypoglycemia.

C-peptide and insulin are secreted in equimolar concentrations in the pancreas, making c-peptide levels a good marker of endogenous insulin secretion. The c-peptide suppression test can be used to test for an insulinoma or to provide supplemental diagnostic information, especially if the results of a supervised fast are not definitive. The c-peptide suppression test must be carefully administered, since the patient is given intravenous insulin to induce hypoglycemia. The advantage of the test is that it is of much shorter duration than the supervised fast. 
The c-peptide suppression test is performed following an overnight fast. The procedure is to infuse regular insulin, $0.125 \mathrm{U} / \mathrm{kg}$ body weight, intravenously over 60 minutes. Blood samples are obtained from the contralateral arm at $0,30,60,90$, and 120 minutes for determination of insulin, cpeptide, and plasma glucose levels. An abnormal result is a lower percentage decrease of c-peptide at 60 minutes compared to normative data appropriately adjusted for the patient's body mass index and age [34]. For example, an abnormal result for a 45-yearold with a BMI of $25-29 \mathrm{~kg} / \mathrm{m}$ would be $<61 \%$ suppression of c-peptide at 60 minutes [35]. An alternative method (Regular insulin $0.075 \mathrm{IU} / \mathrm{kg} \mathrm{hr}$ infused intravenously over 2 hours) using a different classification plot has been proposed [36] but few data using it has been published.

Limitations of this test include that some patients with a documented insulinoma have normal cpeptide levels including normal percent decrease in c-peptide levels. There is also the danger of inducing severe hypoglycemia. In addition, little data concerning the reliability, sensitivity and safety of this test are published.

Imaging: Imaging studies are helpful in endogenous hyperinsulinemic hypoglycemia. These may include computed tomography, magnetic resonance imaging (MRI), and/or transabdominal and endoscopic ultrasonography. Imaging studies are successful in identifying approximately $75 \%$ of insulinomas [37]. Intraoperative pancreatic ultrasonography may also be used to localize small insulinomas not otherwise found with other imaging modalities. Insulinomas are often less than $1.0 \mathrm{~cm}$, so negative imaging does not exclude the diagnosis. In patients with endogenous hyperinsulinemic hypoglycemia, it is sometimes difficult to distinguish between insulinoma and non-insulinoma pancreatogenous hypoglycemia. When noninvasive imaging studies are negative or equivocal, selective arterial calcium injections with measurements of hepatic venous insulin levels can be used to help differentiate insulinoma from diffuse nesidioblastosis [38].

\section{Treatment}

Immediate treatment should be focused on reversing the hypoglycemia. If the patient is able to ingest carbohydrates 15 to 20 grams of glucose should be given every 15 minutes until the hypoglycemia has resolved. If the patient is unable to ingest carbohydrates, or if the hypoglycemic episode is severe, parenteral glucose should be administered. In a healthcare setting intravenous dextrose is used. Twenty five grams boluses of $25 \%$ dextrose are given until the hypoglycemia has resolved. If needed, an infusion of $10 \%$ or $20 \%$ dextrose can be used to sustain euglycemia in patients with recurrent episodes of hypoglycemia.

In the outpatient setting, glucagon, given as an intramuscular injection, is used to correct hypoglycemia. Glucose gel and other forms of oral glucose should be used in impaired patients with caution and only in circumstances where no alternative is available, as they pose an aspiration risk. Long term treatment should be tailored to the specific hypoglycemic disorder, taking into account the burden of hypoglycemia on wellbeing and patient preferences. Offending medications should be discontinued and underlying illnesses treated, whenever possible [26].

a. Dietary Treatment: In non-insulinoma pancreatogenous hypoglycemia, including patients with post Roux en Y gastric bypass hypoglycemia, dietary interventions may be helpful. Frequent feedings and a low carbohydrate diet are common recommendations. Low carbohydrate diets are broadly defined in the literature, with the macronutrient content from carbohydrates ranging from $2 \%$ to $30 \%$. In post Roux-en-Y gastric bypass hypoglycemia, restriction of carbohydrates, and avoidance of high glycemic index foods and simple sugars are recommended. In severe cases gastrostomy tube feeding is sometimes needed [26].

b. Surgical Treatment: Surgical resection can be curative for insulinomas. Most patients with successful surgical removal will have good longterm outcomes $[39,40]$. Surgery can also alleviate hypoglycemia in non-islet cell tumors, even if the cancer cannot be cured. Radiotherapy and chemotherapy can also be used in non-islet cell tumors. Partial pancreatectomy can be considered in patients with non-insulinoma pancreatogenous hypoglycemia. Results of selective arterial calcium stimulation testing can be used to guide the area(s) of resection when partial pancreatectomy is needed [26]. 
c. Medical Treatment: Medical treatment with $\alpha$ glucosidase inhibitors, calcium channel blockers, diazoxide, oroctreotide can be used if resection is not possible in patients with hyperinsulinism, or as a temporizing measure (Table 5).

Table-5: Drug Options for the treatment of serious hypoglycemia [44-47].

\begin{tabular}{|c|c|c|c|}
\hline Medication class & Name & Route & Dosage \\
\hline $\begin{array}{l}\text { Alpha- } \\
\text { glucosidase } \\
\text { inhibitor/ } \\
\text { carbohydrate } \\
\text { digestion and } \\
\text { glucose } \\
\text { absorption } \\
\text { delayed }\end{array}$ & Acarbose & Oral & $\begin{array}{l}50 \mathrm{mg} \\
\text { TID with } \\
\text { meal }\end{array}$ \\
\hline $\begin{array}{l}\text { Calcium channel } \\
\text { blocker/insulin } \\
\text { secretion } \\
\text { inhibitor }\end{array}$ & Verapamil & Oral & $\begin{array}{l}80 \mathrm{mg} \\
\text { BID }\end{array}$ \\
\hline $\begin{array}{l}\text { Vasodilator } \\
\text { /insulin secretion } \\
\text { inhibitor }\end{array}$ & Diazoxide & Oral & $\begin{array}{l}3-8 \\
\mathrm{mg} / \mathrm{kg} / \mathrm{d}\end{array}$ \\
\hline $\begin{array}{l}\text { Somatostatin } \\
\text { analog/insulin } \\
\text { secretion } \\
\text { inhibitor }\end{array}$ & Octreotide & $\mathrm{SC}$ & $\begin{array}{l}100 \mathrm{mcg} \\
\text { BID }\end{array}$ \\
\hline
\end{tabular}

Alpha glucosidase inhibitors (such as acarbose) delay the digestion of ingested carbohydrates, resulting in lower blood glucose concentrations after meals. This medication may be useful in lessening the hyperinsulinism in post Roux-en-Y gastric bypass hypoglycemia. It is typically prescribed as $50 \mathrm{mg}$ three times daily with meals [41-43]. Calcium channel blockers mediate hypoglycemia by inhibiting glucose stimulated insulin secretion from the pancreatic beta cells; verapamil $80 \mathrm{mg}$ twice daily has been reported in the literature, but other agents such as diltiazem and nifedipine have been used as well $[41,43]$. Diazoxide inhibits insulin secretion by opening the
ATP dependent potassium channel of the beta cell in the pancreas. Diazoxide is given orally as 38 $\mathrm{mg} / \mathrm{kg}$ /day divided every 8 to 12 hourly up to 1200 $\mathrm{mg}$ /day. Diazoxide may cause edema, dizziness, nausea and hirsutism, and the dose should be reduced in the presence of renal insufficiency [41] Somatostatin analogs (such as octreotide) inhibit insulin secretion when given in high dose, but may not be as effective as diazoxide. Octreotide is given as a subcutaneous injection $100 \mathrm{mcg}$ twice daily up to $1500 \mathrm{mcg}$ daily $[41,44]$.

Autoimmune hypoglycemic conditions may be treated with either glucocorticoids or immunosuppressants, but these disorders may be self limited. Providing glucose by ingestion of uncooked cornstarch or intra gastric glucose infusion may be necessary in some patients [23].

\section{Conclusion}

Diagnosis and management of spontaneous hypoglycemia involves systematic clinical work-up followed by appropriate laboratory evaluation. Once spontaneous hypoglycemia is diagnosed by Whipple's triad, the underlying pathology should be identified through various biochemical tests and radiological imaging. Management of individual conditions depends on the clinical diagnosis. Tumor-related hypoglycemia can be managed by surgical or medical interventions. Prognosis of the disease depends on the stage and underlying condition, its severity, and its duration. Reactive hypoglycemia is often treated successfully with dietary changes. Because glucose is an obligatory metabolic fuel to brain and neural tissues, hypoglycemia always represents a medical emergency that, if left untreated, can result in permanent brain damage and even death. Patients with spontaneous hypoglycemia suffer from greater mortality rates compared to patients suffering from iatrogenic hypoglycemia, indicating the greater vulnerability of this patient population. This hereby underscores the importance of a complete and correct clinical hypoglycemic evaluation during a hypoglycemic spell. Spontaneous or induced by an appropriate stress test generates the clues for a final diagnosis. The complete hypoglycemic evaluation should comprise plasma glucose, insulin, C-peptide, pro-insulin, $\beta$ hydroxybutyrate, 
and glucose increase after glucagon administration and should screen for circulating oral hypoglycemic agents and insulin antibodies. This approach allows identifying of exogenous sources of hyperinsulinism, insulin autoimmunity and the biochemical entity of endogenous hyperinsulinemic hypoglycemia. Failure to document a focal cause of endogenous hyperinsulinemic hypoglycemia suggests the diagnosis of NIPHS. Irrespective of the exact cause of the spontaneous hypoglycemia, treatment consists of correcting the glycemic state and preventing recurrence.

\section{Acknowledgments}

Authors acknowledge the suggestion and opinions of the following endocrinologists:

Professor Md Faruque Pathan and Professor SM Ashrafuzzaman, Department of Endocrinology, BIRDEM General Hospital and Ibrahim Medical College, Bangladesh; Proessor M A Jalil Ansari, Department of Endocrinology, Dhaka Medical College, Bangladesh; Professor Md Fariduddin, Department of Endocrinology, Bangabandhu Sheikh Mujib Medical University, Bangladesh.

\section{Conflict of interest: None.}

\section{Funding: None}

\section{References}

1. Ross JJ, Vaidya A, Kaiser UB. Interactive medical case. Lying low. $N$ Engl J Med. 2011; e10: 364 .

2. Kandaswamy L, Raghavan R, Pappachan JM. Spontaneous hypoglycemia: diagnostic evaluation and management, Endocrine. 2016; 53: $47-57$.

3. Longo, Fauci, Kasper, Hauser, Jameson, Loscalzo. Harrison's: Principles of Internal Medicine.18th ed. New York: McGraw-Hill. 2012; pp 3003-9.

4. Service FJ. Hypoglycemic disorders. $N$ Engl $J$ Med. 1995; 332: 1144-52.

5. Martens P. Tits J. Approach to the patient with spontaneous hypoglycemia. European $J$ Inter Med. 2014; 25: 415-421.
6. Cryer PE. Glucose homeostasis and hypoglycemia. In: Melmed S, Polonsky KS, Larsen PR, Kronenberg HM, editots. Williams Textbook of Endocrinology.13th ed. Elsevier, New York. 2015; pp 1582-1607

7. Cryer PE, Axelrod L, Grossman AB, Heller SR, Montori VM, Seaquist ER, Service FJ. Evaluation and management of adult hypoglycemic disorders: an Endocrine Society Clinical Practice Guideline. J Clin Endocrinol Metab. 2009; 94: 709-728.

8. Service FJ. Classification of hypoglycemic disorders. Endocrinol Metab Clin N Am. 1999; 28: 501-517.

9. Whipple AO, Frantz VK. Adenoma of islet cells with hyperinsulinism: a review. Ann Surg. 1935; 101: 1299-1335.

10. Whipple AO. The surgical therapy of hyperinsulinism. J Int Chir. 1938; 3: 237-76.

11. Cryer PE, Axelrod L, Grossman AB, Heller SR, Montori VM, Seaquist ER, et al. Evaluation and management of adult hypoglycemic disorders: an Endocrine Society Clinical Practice Guideline. J Clin Endocrinol and Metab. 2009; 94: 709-28.

12. Service FJ. Diagnostic approach to adults with hypoglycemic disorders. Endocrinol Metab Clin North Am. 1999; 28: 519-32.

13. Vaidya A, Kaiser UB, Levy BD, Loscalzo J. Clinical problem-solving. Lying low. $N$ Engl J Med. 2011; 364: 871-5.

14. Svensson AM, McGuire DK, Abrahamsson P, Dellborg M. Association between hyper and hypoglycaemia and 2-year all-cause mortality risk in diabetic patients with acute coronary events. European Heart J. 2005; 26: 1255-61.

15. Pinto DS, Skolnick AH, Kirtane AJ, Murphy SA, Barron HV, Giugliano RP, et al. Ushaped relationship of blood glucose with adverse outcomes among patients with STsegment elevation myocardial infarction. $J \mathrm{Am}$ Coll Cardio. 2005; 46: 178-80.

16. Kosiborod M, Inzucchi SE, Goyal A, Krumholz HM, Masoudi FA, Xiao L, et al. Relationship between spontaneous and iatrogenic hypoglycemia and mortality in 
patients hospitalized with acute myocardial infarction. JAMA. 2009; 301: 1556-64.

17. Cryer, PE, Axelrod L, Grossman AB, Heller SR, Montori VM, Seaquist ER, Service FJ. Evaluation and Management of Adult Hypoglycemic Disorders: An Endocrine Society Clinical Practice Guideline. J Clin Endocrinol Metab. 2009; 94: 709-728.

18. Service FJ. Hypoglycemic disorders. $N$ Engl $J$ Med. 1995; 332: 1144-52.

19. Amiel SA, Sherwin RS, Simonson DC, Tamborlane WV. Effect of intensive insulin therapy on glycemic thresholds for counterregulatory hormone release. Diabetes. 1988; 37: 901-7.

20. Mitrakou A, Fanelli C, Veneman T, et al. Reversibility of unawareness of hypoglycemia in patients with insulinomas. $N$ Engl J Med. 1993; 329: 834-9.

21. Cryer PE. Hypoglycemia in Diabetes: Pathophysiology, Prevalence and Prevention. $2^{\text {nd }}$ Ed. Alexandria, VA. Am Diabetes Assoc 2013.

22. Placzkowski KA, Vella A, Thompson GB, Grant CS, Reading CC, Charboneau JW, et al. Secular trends in the presentation and management of functioning insulinoma at the Mayo Clinic, 1987-2007. J Clin Endocrinol Metab. 2009; 94: 1069-73.

23. Kloppel G, Anlauf M, Raffel A, Perren A, Knoefel WT. Adult diffuse nesidioblastosis: genetically or environmentally induced? Hum Pathol. 2008; 39: 3-8.

24. Hirata Y, IShizu H, Ouchi N, Motomura S, Abe M, Hara Y, et al. Insulin autoiummunity in a case with spontaneous hypoglycemia. $J$ Japanese Diab Soc. 1970; 13: 312-320.

25. Arioglu E, Andewelt A, Diabo C, Bell M, Taylor SI, Gorden P. Clinical course of the syndrome of autoantibodies to the insulin receptor (type B insulin resistance): a 28 year perspective. Medicine. 2002; 81: 87-100.

26. Desimone ME, Weinstock RS. Non-Diabetic Hypoglycemia. Endotext [Internet]. South Dartmouth (MA): MDText.com, Inc.; 2000.

27. Bodnar TW, Acevedo MJ, Pietropaolo M. Management of non-islet-cell tumor hypoglycemia: a clinical review. J Clin. Endocrinol Metab. 2014; 99: 713-722.

28. Fukuda I, Hizuka N, Ishikawa Y, Yasumoto $\mathrm{K}$, Murakami Y, Sata A, et al. Clinical features of insulin-like growth factor-II producing non-islet-cell tumor hypoglycemia. Growth Horm IGF Res. 2006; 16: 211-216.

29. Desimone ME, Weinstock RS. Pancreatic Islet Function Tests. In ENDOTEXT.org. January 26, 2016, published by MDTEXT.COM INC, South Dartmouth MA 02748. PMID: 25905219.

30. Kumar D, Mehtalia SD, Miller LV. Diagnostic use of glucagon induced insulin response. Studies in patients with insulinoma or other hypoglycemic conditions. Ann Intern Med. 1974; 80: 697-701.

31. Hoff AO, Vassilopoulou-Sellin R. The role of glucagon administration in the diagnosis and treatment of patients with tumor hypoglycemia. Cancer. 1998; 82: 1585-92.

32. Marks V, Samols E. Glucagon test for insulinoma: a chemical study in 25 cases. $J$ Clin Path. 1968; 21: 346-352.

33. Luspa BC, Chong AY, Cochran EK, Soos MA, Semple RK, Gorden P. Autoimmune forms of hypoglycemia. Medicine. 2009; 88: 141-53.

34. Marks V. Recognition and differential diagnosis of spontaneous hypoglycaemia. Clin Endocrinol. 1992; 37: 309-16.

35. Service FJ, O'Brien PC, Kao PC, Young Jr WF. C-peptide suppression test: effects of gender, age and body mass index: implications for the diagnosis of insulinoma. $J$ Clin Endocrinol Metab. 1992; 74: 204-210.

36. Saddig C, Bender R, Starke AA. A new classification plot for the C-peptide suppression test. JOP. 2002; 3(1): 16-25.

37. Placzkowski KA, Vella A, Thompson GB, Grant CS, Reading CC, Charboneau JW, Andrews JC, Lloyd RV, Service FJ. Secular trends in the presentation and management of functioning insulinoma at the Mayo Clinic, 1987-2007. J Clin Endocrinol Metab. 2009; 94(4): 1069-73. 
38. Service GJ, Thompson GB, Service FJ,
Andrews JC, CollazoClavell ML, Lloyd RV. Hyperinsulinemic hypoglycemia with nesidioblastosis after gastricbypass surgery. $N$ Engl J Med. 2005; 353: 249-254.

39. Service FJ, McMahon MM, O'Brien PC, Ballard DJ. Functioning Insulinoma incidence, recurrence, and long-term survival of patients: a 60 year study. Mayo Clin Proc. 1991; 66: 711-719.

40. Anlauf M, Wieben D, Perren A, Sipos B, Komminoth P, Raffel A, et al. Perisistent hyperinsulinemic hypoglycemia in 15 adults with diffuse nesidioblastosis: diagnostic criteria, incidence, and characteristics of B cell changes. Am J Surg Pathol. 2005; 29: 524-533.

41. Malik S, Mitchell JE, Steffen K, Engel S, Wiisanen R, Garcia L, Malik SA. Recognition and management of hyperinsulinemic hypoglycemia after bariatric surgery. Obes Res Clin Prac. 2016; 10(1): 1-14.
42. Kelloww TA, Bantle JP, Leslie DB, Redmond JB, Slusarek B, Swan T, Buchwald H, Ikramuddin $\mathrm{S}$. Postgastric bypass hyperinsulinemic hypoglycemia syndrome: characterization and response to diet. Surg Obes Relat Dis. 2008; 4: 492-9.

43. Moreira RO, Moreira RB, Machado NA, Goncalves TB, Continho WF. Postprandial hypoglycemia after bariatric surgery: pharmacologic treatment with verapamil and acarbose. Obes Surg. 2008; 18: 1618-21.

44. Vezzosi D, Bennet A, Rochaix P, Courbon F, Selves J, Pradere B, Buscail L, Susini C, Caron P. Octreotide in insulinoma patients: efficacy on hypoglycemia, relationships with Octreo scan scintigraphy and immunostaining with anti-sst2A and anti-sst5 antibodies. Eur $J$ Endocrinol. 2005; 152: 757-67. 